\title{
HEBDOMON W IDEOLOGII CESARSKIEJ NOWEGO RZYMU WEDŁUG TEKSTU KRONIKI JANA SKYLITZESA
}

\author{
JAROSEAW DUDEK
}

\begin{abstract}
Jarosław Dudek, Hebdomon w ideologii cesarskiej Nowego Rzymu wedtug tekstu kroniki Jana Skylitzesa (Hebdomon in the imperial ideology of New Rome according to a text in the chronicle by John Skylitzes).
\end{abstract}

Balcanica Posnaniensia. Acta et studia, XX, Poznań 2013, Wydawnictwo Instytutu Historii UAM, pp. 25-39, ISBN 978-83-63047-36-1, ISSN 0239-4278. Polish text with a summary in English.

Jarosław Dudek, Uniwersytet Zielonogórski, Instytut Historii, Al. Wojska Polskiego 69, 65-762 Zielona Góra.

Upłynął już wiek od publikacji obszernego studium Dymitra Beljajewa poświęconego ceremonialnym pochodom bizantyńskich cesarzy. Dwadzieścia lat temu ukazała się książka Michaela McCormicka na temat organizacji i przebiegu ceremonii triumfu we wczesnym średniowieczu. W obydwu tych opracowaniach oraz w szeregu pomniejszych tekstach konstantynopolitański Hebdomon zajmuje należne mu miejsce ${ }^{1}$. Wymieniona nazwa pochodzi od greckiego liczebnika ébdomos, nawiązując w swojej

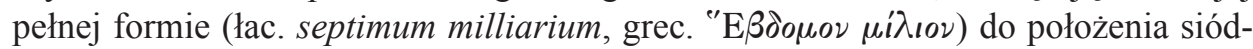
mego kamienia milowego. W tym przypadku należy termin ów rozumieć jako obszar umiejscowiony w odległości siedmiu rzymskich mil (ok. $10 \mathrm{~km}$ ) odliczonych od sym-

${ }^{1}$ D.T. Beljaev, Bogomolnyje vychody vizantijskich carej $v$ gorodskie i prigorodnyje chramy Konstantinopolja, [w:] Zapiski klasičeskogo Otdelenija Imperatoskogo Russkogo Archelogičeskogo Obščestva, t. 4, Sankt-Peterburg 1907, s. 57-92, omówienie starszej literatury poświęconej temu zagadnieniu s. 58-64; M. McCormick, Eternal victory. Triumphal rulership in late antiquity, Byzantium, and the early medieval West, Cambridge 1986. Por. J.-B. Thibaut, L'Hebdomon de Constantinople. Nouvel examen topographique, "Echos d'Orient", 21, 1922, s. 31-44; R. Janin, Constantinople byzantine. Dévelopment urbain et repertoire topographique, Paris 1950, s. 137-139, 408-411; G. Dagron, Naissance d'une capitale: Constantinople et ses institutions de 330 à 451, Paris 1974, s. 99-102; C. Mango, Hebdomon, [w:] The Oxford Dictionary of Byzantium, ed. A.P. Kazhdan, Washington D.C. 1991, (dalej cyt. ODB) t. 1, s. 907 ; P. Stephenson, The Tomb of Basil II, [w:] Zwischen Polis, Provinz und Peripherie. Beiträge zur byzantinischen Geschichte und Kultur, eds. L.M. Hoffmann, A. Monchizadech, Wiesbaden 2005, s. 227-237. Panu Profesorowi Piotrowi Kochankowi z Instytutu Historii KUL pragnę podziękować za wskazówki bibliograficzne dotyczące hebdomońskiego przedmieścia Konstantynopola-Stambułu. 
bolicznego centrum Konstantynopola (Miliarium przy placu Augusteon) do długiej na cztery kilometry równiny nad Morzem Marmara, położonej już poza obrębem murów miejskich. Wybudowane na początkowym odcinku via Egnatia przedmieście (suburbium, pro£steioj, -on) Hebdomon (obecne tur. Bakirköy i Zeytinburnu) już od zarania państwowości bizantyńskiej pełniło ważną rolę w kultywowaniu publicznych form cesarskiego ceremoniału. $Z$ racji swojego przeznaczenia spełniało wymagane kryteria: m.in. odpowiedni obszar, łatwa komunikacja z Miastem. Hebdomon w większości obejmował błonia (Kampos, Tribunalion), mogące pomieścić przynajmniej część mieszkańców kilkusettysięcznego Konstantynopola oraz żołnierzy jego garnizonu. Dalej rozciagała się luźna zabudowa, na którą składały się cesarski pałac, przy którym w V-VI w. odbywały się posiedzenia trybunału, kościoły, klasztory oraz niewielki port również wykorzystywany do celów ceremonialnych. Dostęp do Miasta umożli-

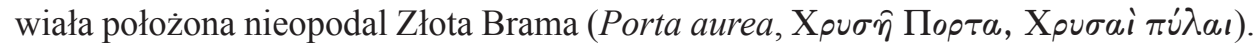
W pierwszym planie budowy Konstantynopola z $330 \mathrm{r}$. jej pierwotna wersja została zaprojektowana jako monumentalne wrota (porta triumphalis) przeznaczone do manifestacji ideologii zwycięstwa. Po rozszerzeniu granic Konstantynopola na początku V w., dotychczasowa Złota Brama została gruntownie przebudowana przybierając formę potrójnych, monumentalnych wrót. Środkowe i najokazalsze zostały przeznaczone dla procesji ceremonialnego cesarskiego orszaku, zaś po bokach dwóch pozostałych pomniejszych bram wybudowano dwie okazałe kamienne wieże. Całość konstrukcji Złotej Bramy włączono w skład Murów Teodozjańskich, co pozwoliło jej przetrwać bez większych szkód do końca historii Bizancjum. W czasach osmańskich Złota Brama znalazła się w obrębie zbudowanego przez sułtana Mehmeda Zdobywcę w 1468 r. więzienia stanu, znanego jako tzw. Zamek Siedmiu Wież (Yedikule)². Natomiast, położone poza fortyfikacjami Konstantynopola budynki hebdomońskiego przedmieścia, zarówno świeckie i sakralne, poważnie ucierpiały w rezultacie arabskich i bułgarskich oblężeń bizantyńskiej stolicy w VII-IX w., stopniowo popadając w ruinę. Pomimo tych ciężkich doświadczeń Hebdomon przez kolejne stulecia nadal zachowywał istotne znaczenie w scenariuszu organizacji wielu cesarskich ceremonii.

Badania nad rangą Hebdomonu w publicznych uroczystościach często opierają się na wybranych partiach utworu $O$ ceremoniach, co jest zrozumiałe uwzględniwszy wartość tego tekstu dla analizy bizantyńskiego ceremoniału ${ }^{3}$. Napisany przez Skylitzesa Zarys dziejów (Synopsis Historion) do tego celu wykorzystywany był rzadziej, chociaż od czasu pierwszej krytycznej edycji upłynęło ponad $30 \mathrm{lat}^{4}$. Z punk-

2 D.T. Beljajev, dz. cyt., s. 10-29; Z. Żygulski, Ceremonialność dworu bizantyńskiego, „Materiały Muzeum Wnętrz Zabytkowych w Pszczynie“, 4, 1987, s. 12-14; C. Mango, The Triumphal Way of Constantinople and the Golden Gate, "Dumbarton Oaks Papers", 54, 2000, s. 173-188; T. Tuna, Bir zamanlar Bakırköy, İstanbul 1996.

${ }^{3}$ Constantini Porphyrogenitii imperatoris De ceremoniis aulae byzantinae, I 91, 96, Appendix ad librum primum, II 19-20, ed. J.J. Reiske, t. 1, Bonn 1829, s. 410-417, 433-440, 495-498, 607-619.

${ }^{4}$ Ioannis Scylitzae Synopsis Historiarum, ed. H. Thurn, Berlin-New York 1973. Zob. M. McCormick, dz. cyt., s. 155-156, przyp. nr 86. Korzystając z niniejszego wydania tekstu pomijam liczne miniatury zachowane na jednej z kopii kroniki, sporządzonej prawdopodobnie w południowej Italii w XII wieku. 
tu widzenia klasyfikacji gatunkowej literatury bizantyńskiej jest to kronika dziejów panowania kolejnych cesarzy od 811 do 1057 roku, którzy z formalnego punktu widzenia pozostają głównymi bohaterami tego tekstu. Skylitzes uwzględnił jednak w jej tekście dodatkowe, zapewne istotne $\mathrm{z}$ jego punktu widzenia wydarzenia, np. objęcie urzędu, depozycję lub zgony patriarchów Konstantynopola, występują się również rozbudowane epizody z udziałem świeckich i kościelnych notabli, czasem autor odtwarza poglądy mieszkańców stolicy czy żołnierzy, wyrażane w związku z czynami konkretnych władców. M. in. z tych powodów można potraktować Zarys dziejów za jeden z wartościowszych tekstów średniowiecznej historiografii bizantyńskiej. O Janie Skylitzesie (ok. 1040 - po 1100) wiadomo niestety niewiele, przede wszystkim, to co sam napisał o sobie we wstępie do tekstu kroniki, przedstawiając się jako kuropalates sprawujący prestiżowy stołeczny urząd drungariosa tes bigles. Podejmowane są próby jego identyfikacji z Janem z temu Trakezjon, dygnitarzem z końca XI wiekus. Przedmieście hebdomońskie pojawia się kilkakrotnie w Zarysie dziejów, odgrywając kilka ról w politycznej obyczajowości prawie trzech wieków. W przekazie Skylitzesa można doszukać się oznak metamorfozy tego miejsca w bizantyńskiej cesarskiej idei.

Charakterystykę zebranych przezeń materiałów wypada rozpocząc od streszczenia pewnego wydarzenia, które przydarzyło się pewnemu młodemu wieśniakowi $\mathrm{z}$ temu macedońskiego w bliżej niesprecyzowanym czasie po $850 \mathrm{r}$. Opuścił on swoją rodzinną wioskę w poszukiwaniu nowych perspektyw życiowych w stołecznej metropolii. Kiedy wieczorem znużony dotarł do celu swojej podróży, jego przybycie do Miasta przez Złotą Bramę (i w domyśle przez Hebdomon) miało cechę niezwykłości. Przybysz nie tylko wszedł do Konstantynopola przez ceremonialne wrota zastrzeżone dla cesarskich procesji, ponadto szybko pozyskał protekcję świętego Diomedesa, którego monaster znajdował się nieopodal. Jego igumenowi przyśnił się patron owej mniszej wspólnoty i zażądał, by natychmiast udzielono gościny ubogiemu wędrowcowi, śpiącemu na ulicy pod klasztornym murem ${ }^{6}$. Ta anegdota nie bez przyczyny została umieszczona przez Skylitzesa w tekście kroniki. Ów niezamożny przybysz to Bazyli Macedończyk, cesarz od 867 r. i założyciel nowej dynastii macedońskiej panującej przez prawie dwieście pięćdziesiąt lat. Niezwykłe okoliczności wejścia młodego wieśniaka do cesarskiego Miasta to symboliczna zapowiedź jego wielkiego przeznaczenia, które wypełniło się we właściwym czasie. Podkreślał to Skylitzes, podążając

\footnotetext{
${ }^{5}$ Ioan. Scylitz. s. $3_{4-6}$. Zob. W. Seibt, Ioannes Skylitzes. Zur Person des Chronisten, "Jahrbuch der Österreichischen Byzantinistik“, 25, 1976, s. 81-85; H. Hunger, Die hochsprachliche profane Literatur der Byzantiner. Bd. 1, Philosophie. Rhetorik, epistolographie, Geschitsschreibung, Geographie, München 1978, s. 389-364; J. Bonarek, Romajowie i obcy w „Kronice“ Jana Skylitzesa. Identyfikacja etniczna Bizantyńczyków i ich stosunek do obcych w świetle „Kroniki“ Jana Skylitzesa, Toruń 2003, s. 15-19; J.-C. Cheynet, Jean Skylitzès. Empereurs de Constantinopole, Texte traduit par B. Flusin, Paris 2003, s. V-XXIV; C. Holmes, Basil II and the governance of Empire (976-1025), Oxford - New York 2005, s. 8091; O. Jurewicz, Historia literatury bizantyńskiej. Zarys, Wrocław-Warszawa 2007, s. 166-168.

${ }^{6}$ Ioan. Scylitz., s. $120_{89-19}$. W kwestii położenia klasztoru św. Diomedesa zob. R. Janin, dz. cyt., s. $168-169$.
} 
śladami historiografów z kręgu Konstantyna VII Porfirogenety, potomka owego biednego wędrowca. Zbliżonej symboliki nabiera informacja o konsekwencjach trzęsienia ziemi z 866 r., kiedy oprócz położonych na hebdomońskim przedmieściu budynków miała również ucierpieć Złota Brama. Jedna z wieńczących jej szczyt figur, statua bogini Nike runęła na ziemię, zapowiadając w ten sposób tragiczne wypadki (kolejne morderstwa na osobach cezara Bardasa i cesarza Michała III) prowadzące do kresu dynastii amorejskiej, którą zastąił nowy ród cesarski założony przez Bazylego ${ }^{7}$.

Te dwa znamiennie wydarzenia nawiązują do funkcji spełnianej przez Hebdomon jako miejsce stanowienia nowego cesarza. Daje to się dostrzec już w epoce wczesnobizantyńskiej, kiedy zgromadzeni na przedmieściu żołnierze i senatorowie proklamowali kolejnych augustów: Walensa (364), Arkadiusza (383), Teodozjusza II (402), Marcjana (450), Leona I (457), Zenona (474), Maurycjusza (582). Tutaj również przeprowadzano do połowy $\mathrm{V}$ stulecia cesarskie koronacje, pozbawione jeszcze chrześcijańskiej ceremonialnej oprawy, chociaż stopniowo aktywnymi uczestnikami tych uroczystości stawali się biskupi Konstantynopola ${ }^{8}$. Dopiero przeprowadzona pod koniec V w. modyfikacja scenariusza cesarskiej proklamacji przeniosła tę ceremonię najpierw do hipodromu, potem kościoła Mądrości Bożej, który od początku VII wieku stał się miejscem ukoronowania większości późniejszych władców bizantyńskich. Miejsce dawnych elekcji nie zostało jednak całkiem pominięte w cesarskiej ceremonii intronizacyjnej. Potwierdzają to przypadki niektórych uzurpatorów z V-VII wieku, Bazyliskosa (475) i Fokasa (602), których proklamowano i ukoronowano w Hebdomon ${ }^{9}$. Również w kronikarskim przekazie Skylitzesa rola owego przedmieścia $\mathrm{w}$ charakterze cesarskiego pola elekcyjnego jest zauważalna $\mathrm{w}$ związku z okolicznościami legitymizacji władzy uzurpatorów w IX-XI w. Teoretycznie osiąnięcie cesarskiej godności w Bizancjum było wyrazem Bożej woli i posiadania zespołu cnót przynależnych monarsze. Jednak w normalnych okolicznościach poddani zwykle akceptowali sukcesję dynastyczną, chociaż dyskretnie ukrywaną pod pozorem zgodnej elekcji ludu i senatu ${ }^{10}$. Tymczasem uzurpatorzy zawdzięczający tron wojsku, jeszcze przed wkroczeniem do Konstantynopola legalizowali swoje wyniesienie zabiegając o poparcie przybyłego na Hebdomon ludu stolicy. Obywatele Miasta wprawdzie rzadko potrafili osadzić na tronie własnego kandydata, zwykle ich udział w wyborze nowego władcy ograniczał się do zaakceptowania elekta wyniesionego uprzednio przez

\footnotetext{
${ }^{7}$ Ioan. Scylitz., s. 107 55-56. Por. Theophanes Continuatus IV 34, ed. I. Bekker, Bonn 1838, S. 197 1-2.

${ }^{8}$ R. Janin, dz. cyt., s. 409; W przypadków niektórych (Walens, Arkadiusz, Teodozjusz II) w Hebdomon miała miejsce ceremonia wywyższenia ich do roli współwładców z woli panujących braci lub ojców. Zob. F. Kolb, Ideał późnorzymskiego władcy. Ideologia i autoprezentacja, przekł. A. Gierlińska, Poznań 2008, s. 97-103.

${ }^{9}$ Ostatni z wymienionych uzurpatorów otrzymał koronę z rąk patriarchy w kościele św. Jana Chrzciciela w Hebdomon. Zob. The Prosopography of Later Roman Empire, vol. III B, ed. J. R. Martindale, Cambridge 1992, hasło "Phocas 5", s. 1030-1032; M.J. Leszka, Uzurpacje w Cesarstwie Bizantyńskim w okresie od IV do połowy IX wieku, Łódź 1999, s. 30-33; G. Dagron, dz. cyt., s. 59-65, 69-73, 78-78.

${ }^{10}$ G. Dagron, s. 14.
} 
armię lub pałacowych dygnitarzy. Uznawano ich jednak za symbolicznych reprezentantów ogółu mieszkańców Cesarstwa, zaś zajęcie stolicy przez uzurpatora często oznaczało przejęcie władzy nad całym państwem. Z tego względu masowy udział Konstantynopolitańczyków w hebdomońskich uroczystościach stanowił ważną formę legitymizowania nowej władzy ${ }^{11}$.

Można to dostrzec, kiedy po przegranej bitwie z Bułgarami pod Bersiniką (22 VI 813 r.) cesarz Michał I Rangabeusz utracił poparcie kół wojskowych. Kilka tygodni później (11 lipca), zebrani na hebdomońskim przedmieściu niezadowoleni dowódcy proklamowali kolejnego cesarza Leona V Armeńczyka (813-820), dotychczasowego stratega temu Anatolikon. Po prawdziwym lub upozorowanym proteście wybraniec został okrzyknięty nowym cesarzem, bezpośrednio potem ukoronowany na oczach żołnierzy i popierających go dygnitarzy. Wówczas otworzyły się przed Leonem bramy stolicy i nowy władca w uroczystym pochodzie dotarł ulicami Miasta do Wielkiego Pałacu, porzuconego przez jego poprzednika, który na wieść o przeprowadzonej na Hebdomon elekcji pośpiesznie szukał azylu w jednym z kościołów ${ }^{12}$.

Zbliżoną rolę odegrały błonia hebdomońskie, kiedy pojawił się pod Konstantynopolem inny pretendent do tronu cesarskiego sławny wódz Nicefor Fokas. Wezwany ze wschodnich prowincji, popierany przez cesarzową-wdowę Teofano, upatrującej w nim najdogodniejszego opiekuna dla jej małoletnich synów, Nicefor na początku sierpnia 963 r. dotarł do Chryzopolis na azjatyckim brzegu Bosforu. W następnych dniach jego stronnicy, dzięki przychylności cesarzowej i niektórych pałacowych dygnitarzy, zdobyli przewagę w Konstantynopolu, po czym wysłali okręty z honorową eskortą po Nicefora. Wówczas: „,przewiozły one Nicefora dostarczając go do Hebdomon, skąd eskorta i wszyscy mieszkańcy poprowadzili go w procesji przez Złotą Bramę do stolicy, z pozdrowieniami i oklaskami, dmąc w rogi i bijąc w czynele". Ceremonia cesarskiej koronacji Nicefora II, dopełniona przez patriarchę Polyeuktosa, w tych okolicznościach została przeprowadzona już w Mieście, w kościele Mądrości Bożej 16 sierpnia 963 r. ${ }^{13}$

Natomiast, z pewnością kłopotliwa dla Skylitzesa, była interpretacja konsekwencji ceremonii, której punktem wyjściowym stał się Hebdomon, dokładnie pięćdziesiąt lat wcześniej, w lecie 913 r. Doszło tam wówczas do spotkania patriarchy Mikołaja Mistyka, opiekuna małoletniego cesarza Konstantyna VII, z Symeonem Wielkim. Jego następstwem była koronacja bułgarskiego władcy, stanowiąca potwierdzenie jego politycznych aspiracji, sięgających nawet cesarskiej godności ${ }^{14}$. W przekonaniu

${ }^{11}$ Zob. M.J. Leszka, Uzurpacje w Cesarstwie Bizantyńskim w okresie od IV do połowy IX wieku, dz. cyt., s. 33, 93-95, 118-121.

12 Ioan. Scylitz., s. $7_{37-4} 41$, s. $8_{67-70^{\circ}}$

${ }^{13}$ Ioan. Scylitz., s. $258_{52-54} \cdot{ }^{67-70}{ }^{\circ}{ }_{60-63}$. Por. De cerimoniis I 96, dz. cyt., s. 436-437. Zob. M. McCormick, dz. cyt., s. 168-169. Według E. Wellesza (Historia muzyki i hymnografii bizantyjskiej, przekł. M. Kaziński, Kraków 2006, s. 111, 124-125.) zespoły muzyków towarzyszących cesarzowi w trakcie dworskich uroczystości składały się z trębaczy grających na rogach, czynelach (tj. metalowych talerzach) i piszczałkach.

${ }^{14}$ Ioan. Scylitz., s. $200_{12-19}$. 
Bizantyńczyków konsekwencje tego wydarzenia stanowiły zagrożenie dla spoistości politycznej rodziny chrześcijańskich królów i książąt, której zwieńczeniem był cesarz panujący w Konstantynopolu. Władca Bułgarów samowolnie porzucał wyznaczony mu w niej uprzednio status, uzurpując sobie niewyobrażalną dlań w ich przekonaniu pozycję. Stąd zapewne brały się usilne starania bizantyńskich dziejopisów w X-XI w., włącznie ze Skylitzesem, zmierzające do zdeprecjonowania rangi tej ceremonii. Według kronikarza Symeon został wówczas obdarowany i uczczony nie cesarskim diademem, tylko używanym przez patriarchę Mikołaja czarnym mniszym nakryciem głowy (epiriptarion) ${ }^{15}$. Uwzględniając wcześniejsze pobyty Symeona w Mieście w charakterze zakładnika (prawd. 878-880, 885-886) i wynikającą z tego faktu dobrą znajomość zasad ceremoniału pałacowego wydaje się mało prawdopodobne, by bułgarski przywódca dał się omamić takim gestem patriarchy. Cesarski tytuł władców Bułgarii został ostatecznie uznany przez Bizancjum dopiero w $927 \mathrm{r}$. Możliwe, że celem Symeona w 913 r. było osiągnięcie tytułu cesarza Bułgarów (basileus ton Bulgaron), natomiast większego zaszczytu, czyli godności cesarza Rzymian (basileus ton Rhomaion), nie był w stanie osiagnąc i jako świadom realiów wytrawny polityk, dobrze to rozumiał. Jednak faktu, że został powitany przez patriarchę, jak nowo wybrany cesarz, nie można bagatelizować. Symbolikę cesarskiej władzy, z którą Hebdomon był związany, Symeon Wielki z pewnością doskonale pojmowa1 ${ }^{16}$.

Wraz z nadejściem jedenastego stulecia zanika funkcja hebdomońskiego przedmieścia jako miejsca stanowienia nowego cesarza. Prawdopodobnie zdążyło być ono jeszcze miejscem publicznego spektaklu towarzyszącego wyniesieniu Konstantyna Monomacha, kiedy w 1042 r. szczęśliwy los uczynił tego arystokratę z zesłańca cesarzem. Skylitzes pisze, że Monomach, jako kolejny kandydat na męża cesarzowej Zoe, dotarł do Damokranei, miejscowości położonej w okolicy miasta trackiego miasta Athyra, zlokalizowanego ok. $30 \mathrm{~km}$ na zachód od Konstantynopola. W Damokranei, w kościele św. Michała Archanioła czekał nań zausznik Zoe, eunuch Stefan z Pergamonu, który przyoblekł go w cesarskie szaty. Następnie, według przekazu kronikarza, nowy władca popłynął statkiem do Miasta, i tego samego dnia (11 VI 1042) poślubił Zoe w Nowym Kościele. Następnego dnia zaś został koronowany przez patriarchę Aleksego Studytę (1025-1043) ${ }^{17}$. Dość oszczędny w detale Skylitzesowy opis tych wydarzeń uzupełnia w swojej Chronografii współczesny kronikarzowi Michał

${ }^{15}$ Ioan. Scylitz., s. $200_{24-27}$ Por. Nicholas I Patriarch of Constantinople, Letters, nr 19, ed. R.J.H. Jenkins, L.G. Westerink, Washington D.C. 1973, s. $128_{22-24}$.

${ }^{16}$ Literatura poświęcona tej ceremonii jest obfita i uwzględnia różne jej warianty interpretacyjne. Zob. m.in. W. Swoboda, Mikołaj Mistyk, [w:] Testimonia najdawniejszych dziejów Słowian, Seria grecka, zeszyt 3, Pisarze z VII-X wieku, red. A. Brzóstkowska, W. Swoboda, Warszawa 1995, s. 371, kom. nr. 41. Por. H. Grala, Uniwersalizm wschodni (idea Cesarstwa Powszechnego w kręu cywilizacji bizantyńskiej), [w:] Pamiętnik XV Powszechnego Zjazdu Historyków, t. 1, cz. 2, red. J. Staszewski, Toruń 1995, s. 144; I. Božilov, Bălgarite văv Vizantijskata imperija, Sofija 1995, s. 88; M.J. Leszka, Wizerunek władców pierwszego państwa butgarskiego w bizantyńskich źródtach pisanych (VIII-pierwsza połowa XII wieku), Łódź 2003, s. 91-93.

${ }^{17}$ Ioan. Scylitz., s. $423_{40-48}, 428_{82}$. Zob. C. Mango, Nea Ekklesia, [w:] ODB (dz. cyt.), t. 2, s. 1146. 
Psellos. Ów sławny pisarz i historyk podkreśla, że eskortowany przez gwardzistów Monomach został pozdrowiony przez senatorów i mieszkańców stolicy, którzy tłumnie przybyli na spotkanie z nowym cesarzem. I chociaż w przekazie Psellosa nie został wzmiankowany Hebdomon, to wnioskując z położenia geograficznego miejscowości wymienionych w kronice Skylitzesa, można założyć, że na błoniach hebdomońskich zorganizowano proklamację Konstantyna Monomacha, reżyserowaną zgodnie ze starym rytem stanowienia bizantyńskich cesarzy ${ }^{18}$. Prawdopodobnie po zakończeniu hebdomońskiej fazy uroczystości Monomach wsiadł na okręt, którym dopłynął do przystani Bukoleon, położonej już w obrębie Wielkiego Pałacu. Stąd skierował się do kościoła położonego w obrębie cesarskiej rezydencji, w którym poślubił Zoe.

W następnych latach nie zabrakło udanych prób zagarnięcia cesarskiej władzy, jednak opisany przez Skylitzesa, kolejny scenariusz intronizacji pozostawał już bez związku z Hebdomonem. Kiedy uzurpator Izaak Komnen, po zwycięstwie pod Niceą (20 VIII 1057) odniesionym nad wojskami Michała VI Stratiotika zbliżył się od wschodu do Miasta, został ogłoszony cesarzem przez notabli zebranych w kościele Mądrości Bożej. Zwycięzca został powitany jeszcze w Azji Mniejszej przez dostojników i delegatów mieszkańców stolicy, po czym przeprawił się na europejski brzeg, wkraczając bezpośrednio do Wielkiego Pałacu, skąd udał się do wymienionego kościoła na uroczystości koronacyjne ${ }^{19}$. Publiczne uroczystości związane $\mathrm{z}$ inauguracją jego panowania odbyły się więc poza Hebdomonem. Chociaż Izaak Komnen, jak i szereg jego następców w XI w. wywodzili się z prowincjonalnych kręgów arystokratycznych, co jednak wcale nie musiało znaczyć, że umniejszali oni rangę stołecznych ceremonialnych uroczystości towarzyszących inauguracji władcy. Przeciwnie, kolejni następcy dynastii macedońskiej wyraźnie dostrzegali potencjał polityczny mieszkańców Konstantynopola i zabiegali o ich akceptację dla swoich rządów. Demonstrowali to jednak w innej formie, zorganizowane przez nich publiczne ceremonie związane $\mathrm{z}$ intronizacją odbywały się wewnątrz Miasta, np. w postaci uroczystej procesji cesarskiego orszaku z Wielkiego Pałacu do kościoła Świętych Apostołów. Uroczystości odbywały się również wewnątrz pałacu cesarskiego, gdzie łączone je z hojnym rozdawnictwem tytułów i pensji dla przywódców stołecznych gildii kupieckich i rzemieślniczych ${ }^{20}$.

18 Michael Psellos, Chronographie ou Histoire d'oun siècle de Byzance (976-1077) VI 19, t. 1, ed. E. Renauld, Paris 1926, s. $126_{1-2}$, s. $127_{3-13}$. Zob. D.R. Reinsch, Pselliana. II. Vor dem Kaiserpalast oder im Gebiet zwischen Athyras und der Landmauer von Konstantinopel? Zum Verständnis von Michael Psellos, "Chronographia” VI 19, "Byzantinische Zeitschrift”, 100, 2007, 1, s. 151-155, zwłaszcza kom. nr 17.

${ }^{19}$ Ioan. Scylitz., s. 499-500. Również w przypadku późniejszych uzurpatorów: Nicefora Botaniaty (1078), Aleksego Komnena (1081) brak dowodów, by przejmując władzę inaugurowali rządy uroczystościami w Hebdomon. Zob. J.-C. Cheynet, Pouvoir et contestations à Byzance (963-1210), Paris 1990, s. $68-69,84-85,89-90$.

20 Ioan. Scylitz., s. 417 93-10. Por. Michael Psellos, Chronographie, V 16, dz. cyt., s. $95_{18}, 96{ }_{1-10^{*}}$. Powyższe dążenia jedenastowiecznych cesarzy, starających się u progu swoich rządów pozyskać życzli-

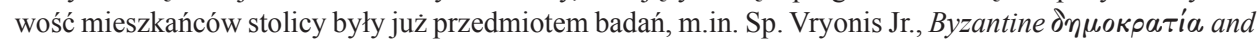
the Guilds in the Eleventh Century, "Dumbarton Oaks Papers", 17, 1963, s. 302-303; L. Garland, Political 
Natomiast w dużym stopniu utrzymał swoją dotychczasową rangę (przynajmniej w pierwszych trzech dekadach XI w.) cesarski adventus imperatoris, stanowiący klasyczną formę demonstracji autorytetu władzy zwierzchniej. W bizantyńskich realiach politycznych adventus łączono często ze zmodyfikowaną wersją starorzymskiego triumfu. Pierwsze fazy uroczystości rozpoczynały się jeszcze daleko od Konstantynopola, w odległości trzech dni drogi od stolicy w Azji Mniejszej lub na Bałkanach, gdzie zwycięzcę witały delegacje dygnitarzy i reprezentantów ludu stolicy. Kolejne jej etapy rozgrywały się w podmiejskich cesarskich rezydencjach wybudowanych na obu brzegach Bosforu w Hieria lub w pałacu świętego Mamasa ${ }^{21}$. Dopiero później orszak zwycięzcy docierał do Hebdomon, gdzie rozgrywał się jeden z kluczowych etapów ceremonii. Uczestniczyli w nim przybyli na błonia mieszkańcy Konstantynopola lub ich reprezentanci. Właściwa uroczystość składała się z dwóch faz. W pierwszej ( $\sigma \nu \nu a ́ \nu \tau \eta \sigma ા \varsigma$, i $\pi \dot{\imath} \nu \tau \eta \sigma !$ occursus) mieszkańcy Miasta gromadzili się za reprezentacyjną bramą oczekując dostojnego gościa, podzieleni według grup

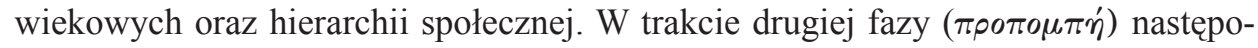
wał uroczysty wjazd cesarza, któremu towarzyszyła zwykle zbrojna eskorta w postaci oddziałów gwardii i wojska. Ten najpierw, kiedy przez Złotą Bramę przybywał do Konstantynopola, udawał się do kościoła Mądrości Bożej, skąd uroczyście wkraczał do Wielkiego Pałacu. Adventus stanowił często jedną z ceremonialnych form towarzyszących intronizacji nowego władcy ${ }^{22}$. Nie było to wszakże jedyne wydarzenie, któremu towarzyszyła taka uroczystość. W niektórych okolicznościach praktykowano również adventus już od IV-V w, witając przybywające do Miasta najcenniejsze relikwie świata chrześcijańskiego. W kronice Skylitzesa można się doszukać elementów inscenizacji tej ceremonii w finałowej fazie translatio mandylionu z Edessy, kiedy relikwia dotarła do stolicy powitana przez cesarską rodzinę i wszystkich mieszkańców w $944 \mathrm{r}^{23}$ Odwrotną formę stanowiła ceremonia profectio, organizowana w trakcie uroczystego wyjazdu cesarza ze stolicy. Powodem do takiego wymarszu, często połączonego z religijnymi obrzędami w najważniejszych sanktuariach Miasta, mógł być początek wyprawy wojennej, czasami był to połączony z pielgrzymką objazd prowincji ${ }^{24}$. Ostatni etap takiej ceremonii odbywał się zazwyczaj w Hebdomon. W kronice Skylitzesa został odnotowany raczej nietypowy przypadek takiego profectio,

Power and the Populace in the Byzantium Prior to the Fourth Crusade, "Byzantinoslavica", 1993, s. 21-22.

${ }^{21}$ R. Janin, dz. cyt., s. 140, 430-431. C. Mango, Hieria, [w:] ODB, dz. cyt., t. 2, s. 929.

22 E.H. Kantorowicz, The "King's Advent" and the enigmatic panels in the doors of Santa Sabina, [w:] Selected Studies, Locust Valley, New York 1965, s. 43-45; S. MacCormack, Change and Continuity in Late Antiquity: the Ceremony of "Adventus”, „Historia. Zeitschrift für alte Geschichte”, 21, 1972, s. 721-752. Szerzej na ten temat wczesnośredniowiecznej recepcji tego ceremoniału pisze J. Lehnen, Adventus principis. Untersuchungen zu Sinngehalt und Zeremoniel der Kaiserankunft in den Städten des Imperium Romanum, Frankfurt/Main 1997; F. Kolb, dz. cyt., s. 39-40.

${ }^{23}$ Ioan. Scylitz., s. $231_{66-68}$, s. $232_{69-72}$. Zob. K.G. Holum, G. Vikan, The Trier Ivory, "Adventus" ceremonial, and the Relics of St. Stephen, "Dumbarton Oaks Papers", 33, 1979, s. 115-133; Ch. Walter, Sztuka i obrzqdek kościoła bizantyńskiego, przekł. K. Malcharek, Warszawa 1992, s. 166-168.

${ }^{24}$ M. McCormick, dz. cyt. s. 246-251, 246. 
w związku z małżeństwem Marii-Ireny, wnuczki cesarza Romana I Lekapenosa (920-944) z carem bułgarskim Piotrem w październiku 927 r., który przybył w tym celu do Konstantynopola. Przedstawicielki bizantyńskiej dynastii panującej w IX-XI w. nieczęsto zawierały związki małżeńskie, w tym czasie sporadyczne były przypadki, aby poślubiały cudzoziemskich władców. Odejście w tym przypadku od dotychczasowej praktyki można tłumaczyć tym, że owo małżeństwo stanowiło jeden $\mathrm{z}$ warunków zakończenia długiej i trudnej wojny z Bułgarami. Rodzice Marii, koregent Krzysztof Lekapenos (921-931) wraz z małżonką Zofią, odprowadzili córkę i jej oblubieńca poza mury miejskie. Kiedy orszak dotarł do Hebdomon, nastąpiło tam pożegnanie Marii z rodzicami, stąd ostatecznie podążyła ona do swojej nowej ojczyzny. Piotr, podobnie jak jego ojciec, uczestniczył w ceremonii odbywającej się w Hebdomon, jednak hierarchia głównych uczestników profectio była już wyraźnie ustalona zgodnie z ówczesną bizantyńską racją stanu i nie budziła takich zastrzeżeń, jak wywyższenie Symeona przed czternastu laty ${ }^{25}$.

W roli jednego z punktów etapowych wyznaczających przebieg uroczystości cesarskich triumfów Hebdomon pojawia się w kronice Skylitzesa kilkakrotnie. Autor skrupulatnie odnotował przebieg procesji triumfalnej Bazylego I Macedończyka, powracającego z swojej pierwszej wyprawy wojennej do Azji Mniejszej w 873 r. Punktem wyjściowym dla trasy cesarskiego pochodu był właśnie Hebdomon. Stąd, po przekroczeniu wrót Złotej Bramy orszak Bazylego podążył przez reprezentacyjne ulice i place Miasta do kościoła Mądrości Bożej, gdzie cesarz odbył dziękczynne modły. Stąd udał się do Wielkiego Pałacu, gdzie uczczono triumfatora i jego najbliższych ceremonialną ucztą. Opis kronikarza, zainspirowany przekazem zaczerpniętym ze starszego Żywotu Bazylego ${ }^{26}$, którego autor podkreślił, że przygotowywano tę uroczystość skrupulatnie naśladując pochody triumfalne dawnych, sławnych rzymskich cesarzy, podążające ustaloną trasą wzdłuż najważniejszych placów i ulic bizantyńskiej stolicy: Forum Teodozjusza, Forum Konstantyna, ulica centralna (Mese), Hipodrom, plac Augusteon. Dalsze uroczystości na cześć Bazylego I kontynuowano w formie uroczystych bankietów w reprezentacyjnych komnatach Wielkiego Pałacu ${ }^{27}$. Cesarski szlak triumfalny był odwzorowywany często w takiej postaci przynajmniej do połowy jedenastego wieku, jednocześnie stanowiąc pewien model organizacji przestrzeni ceremonialnej w niektórych średniowiecznych monarchiach europejskich ${ }^{28}$. Według podobnego rozplanowania przebiegały trasy cesarskich triumfów: Nicefora II Fokasa (965), Jana I Tzymiskesa (971) i Bazylego II (1019). W przekazie Skylitzesa wyeksponowano wprawdzie tylko niektóre fazy powyższych triumfów, organizowane na konkretnych placach i ulicach cesarskiego Miasta. Jednak na podstawie zachowanych

${ }^{25}$ Ioan. Scylitz., s. $224_{59-60^{0}}$ Krzysztof został wyniesiony do rangi współpanującego z woli swojego ojca cesarza Romana I. Zob. J. Shepard, A marriage too far? Maria Lekapena and Peter of Bulgaria, [w:] The Empress Theophano. Byzantium in the West at the turn of the first millennium, ed. A. Davids, Cambridge 1995, s. 121-149, okoliczności zaślubin i ich oprawy ceremonialnej, s. 126-137.

26 Theophanes Continuatus V 40, dz. cyt., s. $271_{2-5}$.

${ }^{27}$ Ioan. Scylitz., s. $137_{56-62}$, s. $138_{63-64}$.

${ }^{28}$ M. McCormick, dz. cyt., s. 289. 
danych z zakresu topografii bizantyńskiej stolicy można z pewną dozą prawdopodobieństwa założyć, że opisane przez kronikarza procesje triumfalne rozpoczynały się na hebdomońskich błoniach. Natomiast mniej precyzyjnie zostały opisane w kronice detale celebracji innych uroczystości tego rodzaju: Bazylego II (989), Michała IV Paflagończyka (1041) czy Konstantyna IX Monomacha (1043).

Triumfy były połączone z prezentacją mieszkańcom stolicy łupów i znamienitych jeńców. W tym kontekście spektakularna wydaje się być oprawa triumfu Jana I Tzymiskesa. Przywiedziony do Konstantynopola wnuk Symeona, Borys II (970-971) został publicznie pozbawiony swoich monarszych insygniów. Uczynił to osobiście Jan Tzymiskes, zabierając Borysowi koronę, którą złożył w dziękczynnym darze na ołtarzu Wielkiego Kościoła. Zdetronizowany władca Bułgarów otrzymał w zamian znaki godności magistra, zostając $\mathrm{w}$ tych okolicznościach włączony do elitarnego kręgu bizantyńskich dygnitarzy ${ }^{29}$. Taka zaszczytna procedura degradacji Borysa zapewne była formą demonstracji zwycięstwa Tzymiskesa nad niepokonanymi dotąd Bułgarami ${ }^{30}$. Pochody Nicefora II Fokasa, Bazylego II i Michała IV Paflagończyka obfitowały w podobne widowiska. W uroczystości zorganizowanej na część Nicefora II eksponowano trofea z cylicyjskiej wyprawy przeciwko muzułmanom, z pośród których kronikarz wymienia pozłacane wrota bram miejskich w Tarsie i Mopsuetii. Pierwsze umieszczono na Akropolu, drugie natomiast osadzono w murach Złotej Bramy ${ }^{31}$. W triumfach Bazylego II z 989 i 1019 r. uczestniczyli znamienici jeńcy: w pierwszym przypadku najbliżsi współpracownicy zabitego uzurpatora Bardasa Fokasa, w drugim natomiast dzieci i wdowa po carze Janie Władysławie ${ }^{32}$. Również w triumfalnym pochodzie Michała IV Paflagończyka pośród pojmanych wrogów pokazanych mieszkańcom stolicy wyróżniał się oślepiony Piotr Deljan, samozwańczy władca zbuntowanych Bułgarów ${ }^{33}$. Natomiast $\mathrm{w}$ przypadku jednego

29 Ioan. Scylitz., s. $310_{54-69^{\circ}}$ Por. Leonis Diaconi Calöensis Historiae Libri Decem, ed. B. Hassi,

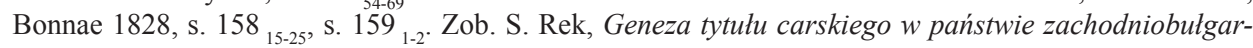
skim, „Balcanica Posnaniensia. Acta et studia”, t. 2, Bułgaria-Bałkany-Słowiańszczyzna, pod red. S. Parnickiego-Pudełko, W. Pająkowskiego, L. Mrozewicza, Poznań 1985, s. 52-53. M.J. Leszka, Wizerunek władców pierwszego państwa bułgarskiego, dz. cyt., s. 141-142.

30 Jego triumf został utrwalony nie tylko przez autora kroniki. Bezpośredni związek ze scenariuszem tej uroczystości mogła posiadać słynna jedwabna tkanina ze skarbca katedralnego z Bambergi, (tzw. całun biskupa Güntera). Została na niej przedstawiona symboliczna scena powitania (occursus) cesarza, przybywającego na białym rumaku. Ceremonii powitania dokonują dwie niewiasty, przypuszczalnie personifikacje dwóch demów: Zielonych i Niebieskich, starożytnych stronnictw cyrkowych, będących nadal symbolicznymi reprezentacjami ludu stolicy Cesarstwa. Zob. G. Prinzing, Das Bamberger Gunthertuch in neuer Sicht, „Byzantinoslavica”, 54, 1993, s. 218-231.

${ }^{31}$ Ioan. Scylitz., s. $270_{34-39^{\circ}}$ M. McCormick, (dz. cyt., s. 170. kom. nr 155) identyfikuje Akropol z pałacem cesarskim. Stąd zdobyczne tarsyjskie wrota miano umieścić w wybudowanym z inicjatywy Nicefora II Fokasa murze, otaczającym Wielki Pałac. Natomiast P. Magdalino (The empire of Manuel I Komnenos, 1143-1180, Cambridge 1990, s. 242, kom. nr 35) sugeruje, że cesarski łup umieszczono w jednej z morskich bram Konstantynopola, w miejscu gdzie rzeczywiście był ongiś położony Akropol antycznego Bizancjum.

32 Ioan. Scylitz., s. $338_{34-35}$, s. $364_{89}$, s. $365_{90-94}$,

33 Ioan. Scylitz., s. $414_{45-46}^{34-35}$. 
z ostatnich pochodów triumfalnych, opisanych w kronice Skylitzesa, najważniejszym trofeum zwycięstwa była głowa uzurpatora Jerzego Maniakesa, poległego w bitwie pod Ostrowem (II 1043). Uroczystość tę od poprzednich triumfów odróżniał fakt, że w triumfalnej procesji jako dowódca zwycięskiej armii wkraczał do Miasta eunuch Stefan z Pergamonu, któremu cesarz Konstantyn IX Monomach powierzył misję pokonania Maniakesa ${ }^{34}$.

Kiedy kronikarz relacjonował podobne uroczystości, do których dochodziło z okazji militarnych sukcesów (niestety coraz rzadszych) późniejszych władców bizantyńskich, milczy na temat roli, którą mógł wówczas odegrać Hebdomon. Możliwe, że pozostawało to $\mathrm{w}$ związku $\mathrm{z}$ kolejną fazą modyfikacji form ceremoniału cesarskiego, czego rezultaty można wyraźnie dostrzec w XII stuleciu. Jak wiadomo, zmiany objęły również scenariusz organizacji cesarskich triumfów. W latach rządów cesarzy z rodu Komnenów miejscem rozpoczęcia uroczystości triumfalnych stała tzw. brama morska, położona we wschodniej części miasta, na obszarze starego Akropolu. Tutaj rozpoczynały się organizowane $\mathrm{z}$ wielkim przepychem i nakładów procesje triumfalne Jana II i Manuela I, zwykle zakończone w kościele Mądrości Bożej35. Jednak pamięć o dawnej tradycji topograficznej scenariusza cesarskiego triumfu długo jeszcze zachowała się wśród bizantyńskich historyków. Była jeszcze aktualna dwa wieki później, kiedy cesarz Michał VIII Paleolog celebrował 15 sierpnia 1261 r. swoje zwycięstwo nad łacinnikami po odzyskaniu Konstantynopola ${ }^{36}$.

Odnotować można również w kronice Skylitzesa oryginalny przypadek wykorzystania hebdomońskiego przedmieścia $\mathrm{w}$ przestrzeni ceremonialnej bizantyńskiej stolicy. Pośród położonych tutaj obiektów sakralnych za najsławniejsze uważano kościoły m.in. pod wezwaniem świętych: Jana Ewangelisty i Jana Chrzciciela, Menasa, Menajosa i Teodoty ${ }^{37}$. Z uwagi na przechowywane w nich relikwie były celem wędrówki dla licznych pielgrzymów w wiekach średnich. Ranga większości tych świątyń nie ucierpiała nawet po zniszczeniach, które dotknęły Hebdomon w rezultacie oblężeń lub trzęsień ziemi. Pierwsze większe prace renowacyjne zostały podjęte prawdopodobnie już z inicjatywy założyciela dynastii macedońskiej, który z atencją odnosił się

34 Ioan. Scylitz., s. 428 93-98. Por. Michael Psellos, Chronographie, VI 86, 87, t. 2, Paris 1928, s. 6-7, gdzie został opisany bardziej szczegółowy scenariusz organizacji tej uroczystości.

35 P. Magdalino, Innovations in government, [w:] Alexios I Komnenos. I. Papers of the second Belfast Byzantine International Colloquium 14-16 April 1989, eds. M. Mullet, D. Smythe, Belfast 1996, s. 156$162,163-164$.

36 Georgii Acropolitae Historia, [w:] Opera, vol. I, ed. P. Wirth, Stuttgart 1978, s. $187_{25-29}$. Skylitzes z perspektywy drugiej połowy XI w. był wyraźnie zgorszony, kiedy opisywał (194 ${ }_{64-67^{\circ}}$ ) gry sportowe organizowane przez dworzan cesarza Aleksandra (912-913) na hebdomońskim placu. Przekaz ten można interpretować również jako zarzut pod adresem władcy, który dopuszcza do swojego najbliższego otoczenia ludzi niskiego pochodzenia. W tym przypadku byłego kapłana Jana, teraz faworyta Aleksandra, który stracił życie w trakcie tych gier.

37 Zestawienie świątyń wybudowanych w Hebdomonie pojawia się w literaturze bizantyńskiej już w VI w. Patrz Prokopiusz z Cezarei, O budowlach, przełożył, wstępem i objaśnieniami i komentarzem opatrzył P.Ł. Grotowski, Warszawa 2006, s. 100, 107, 110. Natomiast J.-B. Thibault, dz. cyt., s. 37-44; R. Janin, dz. cyt., s. 410 publikują zrekonstruowaną listę hebdomońskich obiektów sakralnych. 
do kultu świętego Jana Chrzciciela, inicjując i wspierając renowację poświęconych mu kościołów w stolicy i na prowincji. Natomiast jego praprawnuk Bazyli II musiał żywić szczególną atencję do Jana Ewangelisty. Otóż na krótko przed swoją śmiercią, która nastapiła 15 grudnia w 1025 r., wyraził życzenie, aby zostać pochowanym w zbudowanym czy raczej odbudowanym przezeń klasztorze św. Jana Ewangelisty w Hebdomonie ${ }^{38}$. Ostatnia wola umierającego cesarza była decyzją niezwykłą i wywołała pewne poruszenie pośród współczesnych, bowiem panujący cesarze od IV w., w tym wszyscy członkowie dynastii macedońskiej, byli grzebani w dwóch cesarskich mauzoleach (Konstantyna Wielkiego i Justyniana I) przy kościele Świętych Apostołów $^{39}$. Powód tak niezwyczajnego, przedśmiertnego życzenia Bazylego II nie wydaje się być łatwy do wyjaśnienia. Fakt, że Pole Marsowe starego Rzymu wykorzystywano przed wiekami, jako miejsce pogrzebów i apoteozy zmarłych cesarzy mógł być znany niektórym bizantyńskim literatom w X-XII w. Wydaje się jednak mało prawdopodobne, by chrześcijański cesarz mógł być inspirowany praktykami swoich starożytnych pogańskich poprzedników ${ }^{40}$. W opinii niektórych badaczy wytłumaczenia sensu ostatniej woli Bazylego II można się doszukać w inskrypcji umieszczonej na jego grobie. Oprócz wyliczenia zwycięstw zmarłego cesarza nad muzułmanami i barbarzyńcami zawiera ona wyjaśnienie Bazylego, iż zapragnął znaleźć ostatni spoczynek w Hebdomon po trudach panowania, dlatego odszedł od tradycji swoich cesarskich przodków ${ }^{41}$. Zdaniem Paula Magdalino w tekście inskrypcji występuje pewna gra słów łącząca lokalizację cesarskiego grobu z popularnymi na początku XI stulecia przekonaniami chiliastycznymi o rychłym nadejściu Sądu Ostatecznego. Według wielu bizantyńskich interpretatorów Pisma Świętego (np. Teofaniusza Mnicha, Germana z Konstantynopola, metropolity Bazylego z Neopatras, anonimowego autora Żywotu św. Nifona, Niketasa z Paflagonii, chartofylaksa Antimosa) miało to nastapić tysiąc lat po Narodzinach, ewentualnie po Zmartwychwstaniu. Pierwsza z tych dat, według ery bizantyńskiej przypadała na 6500 AM (992 AD), natomiast druga na rok 6533 AM (1025 AD) lub 6534 AM (1026 AD). W tych okolicznościach nazwę Hebdomon można zinterpretować jako miejsce, gdzie zmarły cesarz Bazyli II spoczął w „siódmym dniu", by oczekiwać rychłego wezwania na Powtórne Przyjście Chrystusa ${ }^{42}$.

${ }^{38}$ Ioan. Scylitz., s. $369_{17-19}$.

${ }^{39} \mathrm{~Np}$. Histoire de Yahyā ibn Sa' $\bar{\imath} d$ d' Antioche, Edition critique du texte arabe prépare par I. Kratchkovsky et tradution française annoté par F. Micheau et G. Tropeau, „Patrologia Orientalis“, 157, 1997, 4, s. 481-483. Zob. Ph. Grierson, The Tombs and Obits of the Byzantine Emperors (337-1042), „Dumbarton Oaks Papers“, 16, 1962, s. 1-63.

${ }^{40}$ Zob. P. Zanker, Apoteoza cesarzy rzymskich. Rytuat i przestrzeń miejska, przekł. L. Olszewski, Poznań 2005, s. 50-54.

${ }^{41}$ S.G. Mercati, Sull'epitafio di Basilio II Bulgaroctonos, L'epitafio di Basilio Bulgaroctonos secondo il codice modense greco 324, „Bessarione”, 25, 1921, 26, 1922, s. 137-142, 220-222, tenże, Collectanea Byzantina, vol. II, Bari 1970, s. 226-231, 232-234. Zob. M. Lauxtermann, Byzantine Poetry and the Paradox of Basil II's Reign, [w:] Byzantium in year 1000, ed. P. Magdalino, Leiden-Boston 2003, s. 211-212; G. Stephenson, dz. cyt., s. 230-231.

42 P. Magdalino, The Year 1000 in Byzantium, [w:] Byzantium in year 1000, ed. P. Magdalino, Leiden-Boston 2003, s. 236-237, 241-244, 259-263, 267-269. 
Jest to hipoteza kusząca, oparta jednak na nieistniejącym już materiale źródłowym. Nagrobna inskrypcja uległa zniszczeniu jeszcze przed 1260 r., stąd jej tekst przetrwał dzięki odpisom. Chociaż Bazyli przez ponad trzydzieści lat prowadził ascetyczny tryb życia, to nie było to jednak jednoznaczne $\mathrm{z}$ wycofaniem się $\mathrm{z}$ aktywności politycznej. Do ostatnich tygodni życia rządził energicznie, poskramiając opozycję i przygotowując się do kolejnych wojen, zwłaszcza do odzyskania Sycylii, utraconej na rzecz muzułmanów przez jego poprzedników w IX w. Również w kronice Skylitzesa brak bezpośrednich odniesień do ewentualnych chiliastycznych przeczuć umierającego cesarza. Wydaje się to być dość istotne, jeśli wziąć pod uwagę, iż autor Zarysu dziejów, podobnie jak wielu bizantyńskich dziejopisów, skrupulatnie odnotowywał szereg klęsk żywiołowych (trzęsienia ziemi, pożary burze, gradobicia), głodu i epidemii, dopatrując się w nich zazwyczaj zapowiedzi jakichś nadzwyczajnych wydarzeń dla swoich władców i rodaków ${ }^{43}$.

Ostatnia wola Bazylego II nie znalazła zbyt wielu naśladowców wśród jego spadkobierców. W klasztorach położonych poza murami Miasta pochowano w XI w. tylko dwóch władców bizantyńskich. Michała IV Paflagończyka, pogrzebano w ostatnich dniach grudnia 1041 r., zgodnie zjego życzeniem, jako mnicha w klasztorze św. Kosmy i Damiana, położonym naprzeciw północno zachodniej części Konstantynopola ${ }^{44}$. Podobnie najmłodsza z bratanic Bazylego, cesarzowa Teodora (jedna z nielicznych kobiet panujących na tronie $\mathrm{w}$ Bizancjum) została $\mathrm{w}$ pierwszych dniach września $1056 \mathrm{r}$. pochowana w niesprecyzowanym klasztorze, usytuowanym na przedmieściu Miasta $^{45}$. Żaden z zachowanych przekazów informujących o tych pogrzebach nie sugeruje, by mogły być one inspirowane lokalizacją grobu Bazylego II. Wprawdzie groby innych cesarzy od połowy XI w. również znajdowały się w fundowanych przez nich klasztorach, ale wyraźnie zlokalizowanych wewnątrz murów Miasta. Stąd pomimo starań P. Magdalino gest cesarza nadal wydaje się pozostawać trudny do jednoznacznego wyjaśnienia, pozostając wyrazistym przykładem osobistej pobożności jednego z najwybitniejszych władców średniowiecznego Bizancjum.

Analizując zawartość kroniki Skylitzesa można się przekonać, że fragmenty dotyczące Hebdomonu, nie są równomiernie rozłożone w jej tekście. Uprzywilejowane pod tym względem wydają się być rządy cesarzy z IX-X wieku. Doszukiwanie się powodów owej dysproporcji w ograniczeniach dostępu autora Zarysu dziejów do materiałów źródłowych raczej nie dostarcza satysfakcjonującego wyjaśnienia. Teksty kronikarskie i biograficzne, którymi posługiwał się Skylitzes, były kompletne. W odniesieniu do lat 813-961 czerpał z utworów kronikarzy pracujących przeważnie pod

\footnotetext{
43 Ioan. Scylitz., s. $107_{51-51}$, s. $221_{93-95}$, s. $225_{90-95}$, s. $226_{2-23}$, s. $277-278$, s. $331_{52-53}$, s. $332_{54-58}$, s. 386 ${ }_{65-70}$, s. 393 , s. $396_{33-35}$, s. $402_{81-84}$, s. $405_{73-79}$, s. $414_{27-28}$, s. $433_{38-39}$, s. $477_{74-78}$. Wprawdzie informację o śmierci Bazylego poprzedza w tekście Zarysu dziejów opis widzenia patriarchy Eustacjusza $\left(368_{88-10}\right)$, w którym pojawiają się dzikie zwierzęta odziane w szaty kapłanów. Jednak prawdopodobnie zapis ów ma związek nie tyle ze śmiercią sędziwego cesarza, co pozostawał formą krytyki wad stołecznego kleru w ówczesnej epoce.

${ }^{44}$ Ioan. Scylitz., s. $414_{46-47}$, s. $415_{48-56^{\circ}}$

${ }^{45}$ Synopsis Chronikē, [w:] Mesaiōnikē Bibliothēkēe, t. 7, ed. K. Sathas, Paris 1894, s. $163_{\text {17-18. }}$
} 
patronatem Konstantyna VII Porfirogenety. Zawartość Zarysu poświęcona temu okresowi w dużym stopniu opiera się na tak zwanej Kontynuacji Teofanesa, na którą złożyły się prace kilku autorów z X wieku. Jednym z nich był sam Porfirogeneta, pozostali są niezidentyfikowani. Skylitzes przeważnie starannie przepisywał ich teksty, nie czyniąc tego jednak mechanicznie, lecz często dokonywał zmian sugerujących, że w ocenie poszczególnych faktów posługiwał się własnymi kryteriami. Wielu swoich poprzedników uznał za stronniczych, stąd jego krytyczna postawa wobec dorobku nadwornej historiografii dynastii macedońskiej. Zdaje się to potwierdzać nierzadkie wykorzystanie przez Skylitzesa tekstów pochodzących z kręgów pisarzy reprezentujących niechętną sukcesorom Bazylego Macedończyka tradycję historiograficzna, np. kronika Symeona Logotety lub zaginione prace historyczne z przełomu X-XI w. Skylitzes raczej krytycznie odnosił się do piśmiennictwa większości współczesnych mu twórców, zwłaszcza do Michała Psellosa. Prawdopodobnie nie korzystał z głównej pracy historycznej (Chronografia) wielkiego pisarza. Prędzej mogła być mu znana przypisywana Psellosowi kronika (Krótka historia) z dziejów rzymskich i bizantyńskich ${ }^{46}$.

Uwzględniając ten hipotetyczny zestaw źródeł dobranych przez Skylitzesa można wnioskować, że kompilował je posługując się kryteriami, odpowiadającymi oczekiwaniom dużej części czytelników jego epoki ${ }^{47}$. Lata tworzenia Zarysu dziejów były trudnymi dla Bizancjum, którego położenie zaczęło się szybko pogarszać po $1056 \mathrm{r}$. wskutek wojen domowych i naporu sąsiednich ludów W tych okolicznościach szczególnie często wyrażana była potrzeba odbudowy autorytetu władcy, czemu służyć miała m.in. ówczesna historiografia. Badacze tekstu Skylitzesa zauważają, że charakteryzując rządy dawnych cesarzy, kronikarz realizował to zadanie z perspektywy akceptowanego w jego czasach, przez arystokrację, katalogu cnót władców. Konstatują, że jednym z celów dziejopisarza było przypomnienie współczesnym dawnej militarnej chwały Cesarstwa ${ }^{48}$. Powyższe stwierdzenie można uzupełnić uwagą, że dla autora Synopsis pojęcie cesarskiego autorytetu wykraczało poza ramy wzorca arystokratycznego władcy-żołnierza. Kronikarz uwzględniał w swoim przesłaniu również inne aspekty cesarskiej ideologii. Afirmacja pewnych form starego ceremoniału i miejsc jego publicznego celebrowania miała powiązanie z inauguracją lub militarnym sukcesem cesarza, co poświadczali tłumnie przybywający na Hebdomon poddani. Był to czynnik, którego Skylitzes starał się nie pominąć, skrupulatnie podkreślając związki swojego utworu z minioną epoką, budząc nadzieję czytelników na szybkie odrodzenie świetności państwa bizantyńskiego.

46 Michaelis Pselli Historia syntomos, ed. W.J. Aerts, Berlin 1990.

47 Potwierdzają to nie tylko częste przypadki wykorzystania kroniki przez bizantyńskich dziejopisów w XII w. (Jerzy Kedrenos, Jan Zonaras, Nicefor Bryennios i in.), jej kontynuacja do 1081 r., oraz interpolacje do jednego z zachowanych rękopisów Zarysu dziejów, dokonane przez jednego z jej czytelników Michała z Dewolu. Zob. D.I. Polemis, Some cases of erroneous identification in the Chronicle of

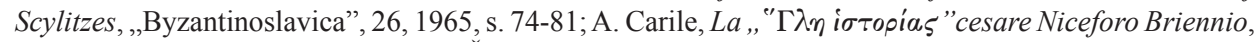
„Aevum”, 43, 1969, 1, s. 56-61; D.A. Černoglazov, Chronika Joanna Zonary i jeji istočniki (IX-XI veka), „Vizantijskij Vremennik”, 63, 2004, s. 137-154.

48 J. Bonarek, dz. cyt., s. 109-110; C. Holmes, dz. cyt., s. 202-203. 


\title{
HEBDOMON IN THE IMPERIAL IDEOLOGY OF NEW ROME ACCORDING TO A TEXT IN THE CHRONICLE BY JAN SKYLITZES
}

\begin{abstract}
Summary
40 years have passed since the critical edition of "An Outline of History" (Synopsis Historion). In terms of the genre classification of the Byzantine literature, it is the chronicle of the history of the reign of the subsequent Byzantine emperors from 811 to 1057. The suburb of Hebdomon appears several times in "An Outline of History" and it plays a number of roles in the political customs of the then Byzantium. It functioned as a place of the enthronement of the Byzantineemperors, their triumphs, their ceremonious arrivals in the capital city, their departures beyond the walls of Constantinople and, in some cases, as a place of their burial. The term "Hebdomon" derives from the Greek numeral ébdomos, and it refers to the Latin expression septimum miliarium. It encompasses an area situated at a distance of seven Roman miles (c. $10 \mathrm{~km}$ ) from the symbolic centre of Constantinople in the Augusteon square.
\end{abstract}


